\title{
Idiopathic Tropical Splenomegaly Syndrome in Ibadan*
}

\author{
E. J. WATSON-WILLIAMS, $†$ M.B., M.R.C.P. ; N. C. ALLAN, $\ddagger$ M.B., M.R.C.P.ED.
}

$S^{\mathbf{u}}$ ummary : Follow-up of 33 patients with idiopathic splenomegaly, 25 for a period ranging from 14 to 80 months after starting treatment with proguanil $100 \mathrm{mg}$. daily, showed that there was an excellent response of the splenomegaly, anaemia, and hepatomegaly, together with a definite gain in weight. Every patient improved, though a maximum result was not attained until after at least one year's treatment.

Therapy with proguanil is considered superior to and safer than splenectomy. Malaria seems unlikely to have a causal role in the aetiology of the disease, which is probably a manifestation of a disorder of the normal immune mechanism. Idiopathic splenomegaly has a close relation with the type of chronic lymphatic leukaemia seen in Nigeria, and it is possible that the two diseases have a similar aetiological factor.

\section{Introduction}

Splenomegaly of variable proportion is not uncommon in Nigeria and other tropical countries. The causes are many but we, like workers in East Africa and New Guinea (Gebbie et al., 1964 ; Pryor, 1967a), have come to recognize a group that appears distinct. The name "big spleen" disease originally bestowed was discussed recently by a large group of workers, and it was recommended that in future it should be discarded in favour of "tropical splenomegaly syndrome" (Brit. med. F., 1967).

The spleen is very large without apparent cause; the liver and, in Nigeria, the bone marrow usually show infiltration by normal lymphocytes. There is moderate anaemia and frequently a loss of musculature. The patients are apyrexial, and show no greater frequency of active infection with malaria parasites than the normal immune population. We began to be interested in this condition in 1960, and originally decided to follow the natural history in an untreated group of patients. However, we had seen several patients with chronic lymphatic leukaemia associated with giant splenomegaly, and noted that the spleen became much smaller when treated with proguanil (Allan and Watson-Williams, 1964). We therefore decided to follow the effects of this antimalaria drug in the tropical splenomegaly syndrome.

\section{Patients and Methods}

There were 33 patients ( 14 males and 19 females) with a spleen extending to at least $10 \mathrm{~cm}$. below the costal margin in whom there was no apparent cause. They were aged 13 to 62 years, and were selected only in so far as they lived close to Ibadan and agreed to long-term treatment and follow-up.

Haemoglobin, haematocrit, white cell count, platelet count, and blood film preparation were carried out with routine methods (Dacie and Lewis, 1963). Haemoglobin electrophoresis was done on paper at $\mathrm{pH} 9$ with a discontinuous tris-barbiturate

* From the Department of Pathology, University of Ibadan, Nigeria. † Present address: Department of Clinical Haematology, University and Royal Infirmary, Manchester 13. ₹ Present address: Department of Haematology, Western General Hospi-
tal, Edinburgh 4 . buffer system $(0.01 \mathrm{M})$. Marrow was aspirated from the left iliac crest, and smears were stained with May, Grünwald, and Giemsa stains. They were reported as showing lymphocytic infiltration if more than $10 \%$ of cells in the marrow were lymphocytes. Liver biopsy specimens were obtained with a Vim-Silverman needle and were reported on by Professor G. M. Edington. Spleen size was recorded as the distance in centimetres from the tip to the left costal margin along the long axis of the spleen. Liver size was recorded as the distance in centimetres from liver edge to the costal margin in the midclavicular line.

\section{Clinical Findings}

History.-In one patient splenomegaly was a chance finding ; all others complained of abdominal swelling for periods of three months to 15 years. Frequently the patient said that it had enlarged rapidly over a period of a few months and then remained static in size for years. Most also complained of lassitude, anorexia, loss of weight, and resultant inability to work.

Clinical Examination.-In general the patients were not severely ill, though those with a long history had poor musculature. None was jaundiced. The spleen was firm, often nodular, but not tender. It varied in size from 10 to $35 \mathrm{~cm}$. below the costal margin, and usually filled the greater proportion of the abdomen. The liver was palpably enlarged in 31 patients, and reached from 1 to $18 \mathrm{~cm}$. below the costal margin. Five patients had doubtfully significant enlargement of cervical lymph nodes.

\section{Haematological Findings}

All patients were anaemic, with haemoglobin values between 5.6 and $12.1 \mathrm{~g} . / 100 \mathrm{ml}$. (mean $9.2 \mathrm{~g} . / 100 \mathrm{ml}$.) in the males and 6.4 and $11.4 \mathrm{~g} . / 100 \mathrm{ml}$. (mean $8.5 \mathrm{~g} . / 100 \mathrm{ml}$.) in the females (Tables I and II). The white cells varied from 1,400 to $22,400 /$ cu. mm. (mean 7,000/cu. mm.). Though in 12 patients lymphocytes accounted for more than $60 \%$ of white cells, the total lymphocytes were over $4,500 / \mathrm{cu}$. $\mathrm{mm}$. in only eight. Ten patients had eosinophil counts of more than $400 / \mathrm{cu}$. $\mathrm{mm}$. Platelets were between 70,000 and $250,000 / \mathrm{cu}$. mm.

There was no correlation between the size of the spleen, the stated duration of symptoms, and the degree of peripheral blood abnormality.

The bone marrow was examined in 23 patients and showed lymphocytic infiltration in 16 ; megaloblastic erythropoiesis was present in four. Liver biopsy was carried out in seven cases, and in six showed periportal lymphocytic infiltration; in four this was associated with marrow infiltration, which was also present in the one case in which a liver biopsy was normal.

Haemoglobin electrophoresis was done in 29 patients; three had haemoglobin $\mathrm{C}$ trait, one had sickle-cell trait, and the others showed only normal haemoglobin.

\section{Response to Treatment with Proguanil}

Twenty-five (12 males and 13 females) were given proguanil $100 \mathrm{mg}$. daily for at least a year. No other treatment and no 
advice on diet was given. Twenty-four patients improved remarkably, and were able to return to work. Reduction in size of the spleen and liver and a rise in haemoglobin were usually first apparent after three months, but maximum results took up to 40 months (Table I gives the details). There was no significant change in white cell counts, but the platelet count became normal in all except one case. One patient whose marrow was heavily infiltrated with lymphocytes still showed this after one year, but after 24 months of continuous treatment the marrow had returned to normal. In the four patients with megaloblastic erythropoiesis the anaemia recovered as quickly as in the others, though folic acid was not given.

TABLE I.-Results of Treatment with Proguanil $100 \mathrm{mg}$. Daily for at Least One Year in 25 Patients with Idiopathic Tropical Splenomegaly

\begin{tabular}{|c|c|c|c|c|c|c|c|c|c|c|c|c|}
\hline \multirow[b]{2}{*}{$\begin{array}{l}\dot{0} \\
\mathbf{Z} \\
\tilde{\Xi} \\
\tilde{J} \\
\tilde{U}\end{array}$} & \multirow{2}{*}{\multicolumn{2}{|c|}{ 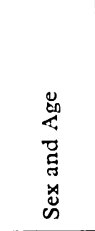 }} & \multicolumn{2}{|c|}{$\begin{array}{c}\text { Spleen } \\
(\mathrm{cm} .)\end{array}$} & \multicolumn{2}{|c|}{$\begin{array}{l}\text { Liver } \\
(\mathrm{cm} .)\end{array}$} & \multicolumn{2}{|c|}{$\mathrm{Hb}(\mathrm{g} . / 100 \mathrm{ml})}$. & \multicolumn{2}{|c|}{ Weight (kg.) } & \multicolumn{2}{|c|}{$\begin{array}{c}\text { Period } \\
\text { (months) }\end{array}$} \\
\hline & & & 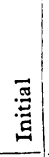 & 茎 & $\underset{\Xi}{\overparen{\Xi}}$ & 茎 & 烝 & 茎 & $\underset{\Xi}{\stackrel{\Xi}{\Xi}}$ & 嵒 & 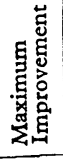 & 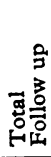 \\
\hline $\begin{array}{r}1 \\
2 \\
3 \\
4 \\
5 \\
6 \\
7 \\
8 \\
9 \\
10 \\
11 \\
12 \\
13 \\
14 \\
15 \\
16 \\
17 \\
18 \\
19 \\
20 \\
21 \\
22 \\
23 \\
24 \\
25\end{array}$ & $\begin{array}{l}M \\
M \\
\mathrm{~F} \\
\mathrm{M} \\
\mathrm{F} \\
\mathrm{M} \\
\mathrm{F} \\
\mathrm{F} \\
\mathrm{F} \\
\mathrm{M} \\
\mathrm{M} \\
\mathrm{M} \\
\mathrm{F} \\
\mathrm{F} \\
\mathrm{F} \\
\mathrm{F} \\
\mathrm{F} \\
\mathrm{M} \\
\mathrm{M} \\
\mathrm{F} \\
\mathrm{M} \\
\mathrm{F} \\
\mathrm{M} \\
\mathrm{M} \\
\mathrm{F}\end{array}$ & $\begin{array}{l}45 \\
35 \\
37 \\
62 \\
45 \\
13 \\
20 \\
27 \\
43 \\
45 \\
26 \\
60 \\
50 \\
? \\
60 \\
33 \\
45 \\
40 \\
50 \\
40 \\
38 \\
45 \\
55 \\
22 \\
56\end{array}$ & $\begin{array}{l}19 \\
30 \\
20 \\
27 \\
15 \\
20 \\
21 \\
20 \\
18 \\
10 \\
11 \\
14 \\
21 \\
28 \\
28 \\
15 \\
16 \\
24 \\
13 \\
21 \\
21 \\
19 \\
14 \\
35 \\
14\end{array}$ & $\begin{array}{r}0 \\
1 \\
4 \\
0 \\
2 \\
1 \\
8 \\
7 \\
10 \\
0 \\
5 \\
0 \\
11 \\
6 \\
6 \\
6 \\
0 \\
0 \\
2 \\
8 \\
5 \\
4 \\
0 \\
21 \\
2\end{array}$ & $\begin{array}{r}8 \\
1 \\
11 \\
7 \\
8 \\
6 \\
1 \\
8 \\
0 \\
8 \\
6 \\
0 \\
5 \\
10 \\
2 \\
6 \\
6 \\
7 \\
1 \\
4 \\
9 \\
4 \\
11 \\
7 \\
10\end{array}$ & $\begin{array}{l}2 \\
0 \\
0 \\
0 \\
7 \\
0 \\
0 \\
8 \\
1 \\
0 \\
0 \\
1 \\
2 \\
0 \\
0 \\
3 \\
0 \\
0 \\
0 \\
* \\
3 \\
0 \\
0 \\
3 \\
2\end{array}$ & $\begin{array}{r}7.5 \\
10 \cdot 1 \\
9 \cdot 8 \\
7 \cdot 5 \\
9 \cdot 2 \\
5 \cdot 6 \\
7 \cdot 8 \\
6 \cdot 4 \\
8 \cdot 2 \\
9 \cdot 7 \\
10 \cdot 3 \\
7 \cdot 8 \\
9 \cdot 6 \\
7 \cdot 4 \\
10 \cdot 7 \\
10 \cdot 0 \\
8 \cdot 8 \\
6 \cdot 4 \\
10 \cdot 8 \\
11 \cdot 4 \\
9 \cdot 6 \\
7.8 \\
9 \cdot 0 \\
11.4 \\
7.9\end{array}$ & $\begin{array}{l}15 \cdot 0 \\
17.1 \\
13.5 \\
15.1 \\
12.5 \\
13.6 \\
13.6 \\
10.0 \\
10.5 \\
14.0 \\
13.6 \\
12.3 \\
11 \cdot 4 \\
12.9 \\
13.2 \\
11.0 \\
12.5 \\
13.1 \\
14 \cdot 4 \\
13.6 \\
15.4 \\
13.6 \\
15.0 \\
16.5 \\
15.8\end{array}$ & $\begin{array}{r}53 \\
54 \\
54 \\
68 \\
* \\
33 \\
* \\
4 \\
43 \\
56 \\
* \\
57 \\
42 \\
52 \\
59 \\
48 \\
44 \\
* \\
61 \\
* \\
* \\
44 \\
58 \\
52 \\
57\end{array}$ & $\begin{array}{r}57 \\
55 \\
70 \\
79 \\
52 \\
48 \\
* \\
50 \\
50 \\
56 \\
* \\
58 \\
42 \\
53 \\
65 \\
51 \\
50 \\
* \\
64 \\
* \\
* \\
46 \\
60 \\
55 \\
64\end{array}$ & $\begin{array}{l}26 \\
14 \\
31 \\
18 \\
19 \\
35 \\
12 \\
13 \\
15 \\
12 \\
13 \\
13 \\
14 \\
14 \\
15 \\
18 \\
18 \\
18 \\
21 \\
21 \\
24 \\
26 \\
30 \\
31 \\
42\end{array}$ & $\begin{array}{l}42 \\
17 \\
72 \\
21 \\
74 \\
78 \\
43 \\
36 \\
80 \\
42 \\
18 \\
67 \\
14 \\
14 \\
15 \\
18 \\
18 \\
45 \\
28 \\
21 \\
49 \\
26 \\
67 \\
54 \\
65\end{array}$ \\
\hline
\end{tabular}

Eight patients (two males and six females) were treated for less than a year, and then were lost to follow-up. In all of them there had been some improvement (Table II).

TABLE II.-Results of Treatment with Proguanil $100 \mathrm{mg}$. Daily for Less Than One Year in Eight Patients with Idiopathic Tropical Splenomegaly

\begin{tabular}{|c|c|c|c|c|c|c|c|c|c|}
\hline \multirow{2}{*}{$\begin{array}{l}\text { Case } \\
\text { No. }\end{array}$} & \multirow{2}{*}{\multicolumn{2}{|c|}{ Sex and Age }} & \multicolumn{2}{|c|}{ Spleen $(\mathrm{cm})}$. & \multicolumn{2}{|c|}{ Liver (cm.) } & \multicolumn{2}{|c|}{$\mathrm{Hb}(\mathrm{g} . / 100 \mathrm{ml})}$. & \multirow{2}{*}{$\begin{array}{l}\text { Months } \\
\text { Treated }\end{array}$} \\
\hline & & & Initial & Final & Initial & Final & Initial & Final & \\
\hline $\begin{array}{l}26 \\
27 \\
28 \\
29 \\
30 \\
31 \\
32 \\
33\end{array}$ & $\begin{array}{l}\mathrm{F} \\
\mathrm{F} \\
\mathrm{F} \\
\mathrm{F} \\
\mathrm{F} \\
M \\
\mathrm{~F} \\
\mathrm{M}\end{array}$ & $\begin{array}{l}42 \\
30 \\
53 \\
28 \\
32 \\
50 \\
20 \\
45\end{array}$ & $\begin{array}{l}27 \\
12 \\
28 \\
15 \\
20 \\
19 \\
25 \\
16\end{array}$ & $\begin{array}{r}12 \\
4 \\
16 \\
7 \\
8 \\
6 \\
7 \\
13\end{array}$ & $\begin{array}{r}18 \\
5 \\
12 \\
1 \\
3 \\
3 \\
5 \\
6\end{array}$ & $\begin{array}{l}5 \\
4 \\
4 \\
2 \\
0 \\
4 \\
4 \\
6\end{array}$ & $\begin{array}{r}7 \cdot 9 \\
9 \cdot 2 \\
6 \cdot 7 \\
11 \cdot 4 \\
8 \cdot 2 \\
8 \cdot 6 \\
6 \cdot 9 \\
12 \cdot 1\end{array}$ & $\begin{array}{l}12.0 \\
12.0 \\
11.7 \\
13.3 \\
11.4 \\
13.6 \\
12.5 \\
14.0\end{array}$ & $\begin{array}{r}4 \\
4 \\
4 \\
5 \\
5 \\
7 \\
7 \\
10\end{array}$ \\
\hline
\end{tabular}

Gain in weight was considerable $(6-16 \mathrm{~kg}$.) in seven, slight in 9, nil in two, and not recorded in seven patients treated for at least a year. The mean gain was $4.4 \mathrm{~kg}$. in males and $5 \mathrm{~kg}$. in females. Loss of weight was never encountered.

If the final results are judged by reduction in spleen size they were better in males than in females. If judged by gain in haemoglobin the results were equally good, with a mean increase of $5.8 \mathrm{~g} . / 100 \mathrm{ml}$. in males and $4.4 \mathrm{~g}$. $/ 100 \mathrm{ml}$. in females. There was no correlation between initial spleen size, liver size, haemoglobin level, or duration of symptoms and eventual results, but the final result was less satisfactory in those patients whose liver remained enlarged (Table III).

Effect of Stopping Proguanil.-One woman stopped treatment at our suggestion, and two men and four women stopped of their own accord. All six were in good health at the time. Between 1 and 33 months later the patients were seen again,
TABLE III.-Relation Between Final Liver Size and Result

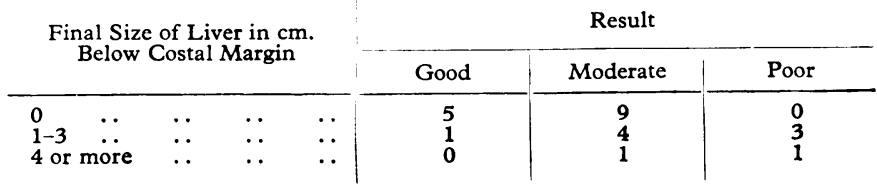

Good result is defined as normal haemoglobin level and impalpable spleen. Poor result is defined as reduced haemoglobin level and palpable spleen.

and in most the spleen had returned to near its original size. Once again there was improvement with proguanil. Two patients (Cases 5 and 6 ) failed to continue treatment on several occasions during the total follow-up period of seven years. On every occasion splenomegaly and anaemia returned after a period of about six months. The longer the interval off treatment the greater the anaemia. (These findings are summarized in Table IV.)

TABLE IV.-Patzents on Interrupted Treatment with Proguanil $100 \mathrm{mg}$. Daily

\begin{tabular}{|c|c|c|c|c|c|c|c|c|}
\hline $\begin{array}{l}\text { Case } \\
\text { No. }\end{array}$ & Age & Sex & $\begin{array}{c}\text { Period } \\
\text { in Months }\end{array}$ & Treated & $\underset{(\mathrm{g} . / 100 \mathrm{ml} .)}{\mathrm{Hb}}$ & $\begin{array}{l}\text { Spleen } \\
(\mathrm{cm} .)\end{array}$ & $\begin{array}{l}\text { Liver } \\
\text { (cm.) }\end{array}$ & $\begin{array}{c}\text { Weight } \\
(\mathrm{kg} .)\end{array}$ \\
\hline 3 & 37 & $F\{$ & $\begin{array}{l}39 \\
33\end{array}$ & $\begin{array}{l}\text { Yes } \\
\text { No }\end{array}$ & $\begin{array}{r}9.8 \\
13.5 \\
13.2\end{array}$ & $\begin{array}{r}20 \\
4 \\
22\end{array}$ & $\begin{array}{r}11 \\
0 \\
9\end{array}$ & $\begin{array}{l}54 \\
70 \\
58\end{array}$ \\
\hline 4 & 62 & $M\{$ & $\begin{array}{r}26 \\
7 \\
2 \\
9\end{array}$ & $\begin{array}{l}\text { No } \\
\text { Yes } \\
\text { No } \\
\text { Yes }\end{array}$ & $\begin{array}{r}7 \cdot 0 \\
7 \cdot 5 \\
14 \cdot 7 \\
14 \cdot 7 \\
15 \cdot 1\end{array}$ & $\begin{array}{c}++ \\
27 \\
5 \\
13 \\
0\end{array}$ & $\begin{array}{r}++ \\
7 \\
0 \\
6 \\
0\end{array}$ & $\begin{array}{l}67 \\
68 \\
73 \\
74 \\
79\end{array}$ \\
\hline 5 & 45 & $F\{$ & $\begin{array}{r}19 \\
5 \\
34 \\
1 \frac{1}{2} \\
15\end{array}$ & $\begin{array}{l}\text { Yes } \\
\text { No } \\
\text { Yes } \\
\text { No } \\
\text { Yes }\end{array}$ & $\begin{array}{r}6 \cdot 9 \\
12 \cdot 5 \\
8.0 \\
* \\
10 \cdot 7 \\
14.3\end{array}$ & $\begin{array}{r}16 \\
2 \\
11 \\
2 \\
9 \\
1\end{array}$ & $\begin{array}{r}12 \cdot 5 \\
7 \\
15 \\
7 \\
12 \\
7\end{array}$ & $\begin{array}{r}* \\
52 \\
50 \\
53 \\
*\end{array}$ \\
\hline & 13 & $M\{$ & $\begin{array}{r}8 \\
16 \\
11 \\
3 \\
12 \\
28\end{array}$ & $\begin{array}{c}\text { Yes } \\
\text { No } \\
\text { Yes } \\
\text { No } \\
\text { Yes } \\
\text { Most of } \\
\text { time }\end{array}$ & $\begin{array}{r}5 \cdot 6 \\
10 \cdot 1 \\
7 \cdot 8 \\
13 \cdot 6 \\
11 \cdot 5 \\
14 \cdot 0 \\
14 \cdot 3\end{array}$ & $\begin{array}{r}20 \\
0 \\
12 \\
1 \\
4 \\
0 \\
0\end{array}$ & $\begin{array}{l}6 \\
0 \\
1 \\
0 \\
0 \\
0 \\
0\end{array}$ & $\begin{array}{r}33 \\
* \\
39 \\
48 \\
50 \\
* \\
53\end{array}$ \\
\hline 7 & 20 & $\mathbf{F}\{$ & $\begin{array}{r}4 \\
12 \\
23 \\
4\end{array}$ & $\begin{array}{l}\text { No } \\
\text { Yes } \\
\text { No } \\
\text { Yes }\end{array}$ & $\begin{array}{r}5.8 \\
7.8 \\
13.6 \\
11.4\end{array}$ & $\begin{array}{c}+++ \\
21 \\
8 \\
20 \\
12\end{array}$ & $\begin{array}{l}5 \\
1 \\
0 \\
0 \\
0\end{array}$ & $\begin{array}{r}45 \\
* \\
* \\
44\end{array}$ \\
\hline 8 & 27 & $\mathbf{F}\{$ & $\begin{array}{r}1 \\
13 \\
10 \\
12\end{array}$ & $\begin{array}{l}\text { No } \\
\text { Yes } \\
\text { No } \\
\text { Yes }\end{array}$ & $\begin{array}{r}6 \cdot 4 \\
6 \cdot 4 \\
10 \cdot 0 \\
7 \cdot 8 \\
13 \cdot 5\end{array}$ & $\begin{array}{c}++ \\
20 \\
7 \\
24 \\
6\end{array}$ & $\begin{array}{l}* \\
8 \\
8 \\
9 \\
0\end{array}$ & $\begin{array}{r}* \\
50 \\
51 \\
51\end{array}$ \\
\hline 9 & 43 & F & $\begin{array}{l}14 \\
15 \\
40 \\
11\end{array}$ & $\begin{array}{l}\text { No } \\
\text { Yes } \\
\text { No } \\
\text { Yes }\end{array}$ & $\begin{array}{r}8 \cdot 1 \\
8 \cdot 2 \\
10.5 \\
* \\
11 \cdot 0\end{array}$ & $\begin{array}{c}+++ \\
18 \\
10 \\
16 \\
11\end{array}$ & $\begin{array}{l}0 \\
0 \\
1 \\
2 \\
2\end{array}$ & $\begin{array}{r}43 \\
50 \\
* \\
47\end{array}$ \\
\hline
\end{tabular}

Final Results.-Twenty-five patients were followed for at least 12 months-14 for over three years, 7 for over five years, and 4 for over six years. All but one were well when last seen. This patient (Case 2) developed a reticulum-cell sarcoma after 17 months of treatment, and is believed to have died from this cause.

\section{Case 1}

A 45-year-old farmer presented with the complaint of a hard mass in the abdomen steadily increasing in size for about one year, mass in theakness, loss of appetite and weight, and periodic diarrhoea for three months. He had a cough for one week. He was seen to be ill, with signs of bronchitis; spleen was $19 \mathrm{~cm}$. and liver $8 \mathrm{~cm}$. below the costal margin; haemoglobin 7.5 g./100 ml. and W.B.C. $22,000 /$ cu. mm. (60\% neutrophils, $37 \%$ lymphocytes). The red cells showed anisocytosis, polychromasia, and occasional nucleated red cells. Weight $53 \mathrm{~kg}$.

On admission the chest $x$-ray film was clear, but within a few days consolidation appeared. After treatment of the bronchitis and pneumonia the W.B.C. was $7,100 / \mathrm{cu}$. mm. (47\% neutrophils, $37 \%$ lymphocytes). Spleen size remained unaltered. The bone marrow was within normal limits, but a liver biopsy showed sinusoids packed 
with small lymphocytes, occasional plasma cells, and fibroblasts. The plasma proteins were: albumin $1.9 \mathrm{~g}$. and globulin $4.6 \mathrm{~g} . / 100 \mathrm{ml}$. $\left(\alpha_{1} 0.5\right.$ g., $\alpha_{2} 0.3$ g., $\beta 0.8$ g., and $\gamma 3.0$ g. $/ 100 \mathrm{ml}$. $)$. He was given chloroquine $400 \mathrm{mg}$. and then proguanil $100 \mathrm{mg}$. daily. In 13 months the spleen was almost impalpable, and his weight was $57 \mathrm{~kg}$. (Fig. 1). He was treated for a total of 42 months, when his spleen was still impalpable but the liver was palpable $2 \mathrm{~cm}$. below the costal mergin.

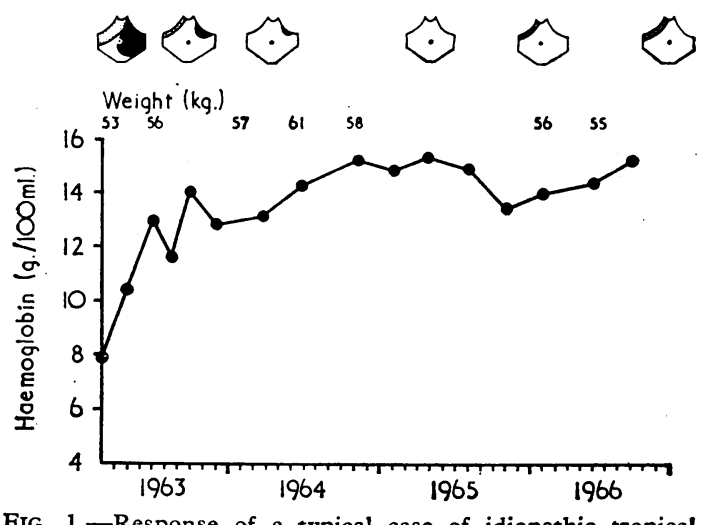

FIG. 1.-Response of a typical case of idiopathic tropical splenomegaly (Case 1) to treatment with proguanil $100 \mathrm{mg}$. daily for four years.

\section{Case 2}

A 35-year-old man complained of an abdominal mass for three years. The spleen extended to $30 \mathrm{~cm}$. below the costal margin, but the liver was only $1 \mathrm{~cm}$. enlarged. Fourteen months after starting treatment with proguanil his spleen was $1 \mathrm{~cm}$. below the costal margin, his liver was impalpable, and his haemoglobin had increased from 10.1 to $17.1 \mathrm{~g} . / 100 \mathrm{ml}$. After remaining well for another three months he complained of fever, loss of weight, and tender swelling over his sternum and right costal margin. The lumps were superficial and did not involve the bone, and on biopsy showed features intermediate between Hodgkin's disease and reticulum-cell sarcoma. A skeletal survey was negative. The bone marrow was infiltrated by large mononuclear cells suggestive of reticulum cells. After a short improvement induced by cyclophosphamide lasting two months he developed pain in the back and in the right humerus, and thereafter failed to attend the clinic. It is presumed that he died from the neoplastic disease.

\section{Case 3}

A 37-year-old woman was admitted in January 1961 complaining of an abdominal swelling, weakness, and fever for three months. She had been amenorrhoeic for three years. The spleen was $20 \mathrm{~cm}$. and the liver $11 \mathrm{~cm}$. below the costal margin. Her weight was $54 \mathrm{~kg}$. Haemoglobin was $9.8 \mathrm{~g} . / 100 \mathrm{ml}$. and W.B.C. 3,200/cu. $\mathrm{mm}$.
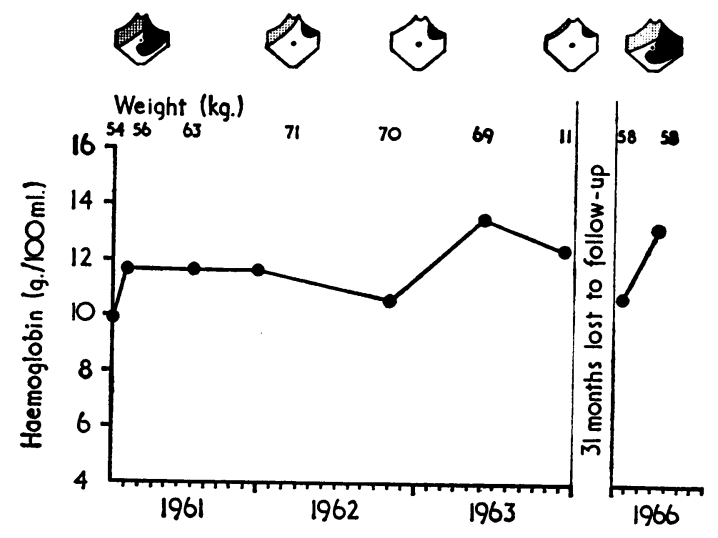

FIG. 2.-Case 3. After an excellent response to proguanil $100 \mathrm{mg}$. daily continued for three years the patient was not seen until 31 months after stopping treatment, when a complete relapse had occurred.
(44\% neutrophils, $48 \%$ lymphocytes, 3\% eosinophils, $5 \%$ monocytes). Splenectomy was attempted but abandoned because of adhesions to the surrounding structures. The para-aortic lymph nodes were much enlarged but discrete. A liver biopsy showed periportal lymphocytic infiltration and she was referred to our clinic with a diagnosis of lymphosarcoma. The bone marrow showed a marked infiltration by mature and primitive lymphocytes.

After one year's treatment with proguanil the spleen was only $4 \mathrm{~cm}$. and the liver $6 \mathrm{~cm}$. below the costal margin. Her haemoglobin had increased to $11.5 \mathrm{~g} . / 100 \mathrm{ml}$. and her weight to $70 \mathrm{~kg}$. (Fig. 2). She returned to work as a market trader. The marrow still showed lymphocytic infiltration, but this had cleared after two years' treatment, by which time the liver was not enlarged, the spleen was $4 \mathrm{~cm}$. below the costal margin, and the haemoglobin was $13.5 \mathrm{~g} . / 100 \mathrm{ml}$. After three years' treatment there was little further change, and she failed to attend.

Thirty-one months later she returned with a prolapsed uterus, and was admitted for vaginal hysterectomy. The spleen had returned to $22 \mathrm{~cm}$. and the liver to $9 \mathrm{~cm}$. below the costal margin. She had lost $13 \mathrm{~kg}$. in weight and her haemoglobin was $11.1 \mathrm{~g}$./ $100 \mathrm{ml}$. Proguanil therapy was reinstituted, and after one month the spleen had regressed by $2 \mathrm{~cm}$.

\section{Case 4}

A 62-year-old farmer complained of abdominal swelling for 15 years with lassitude and dyspnoea on exertion. He had been unable to work for four years. His original admission in January 1960 was for pneumonia, but two months later he was readmitted for investigation of his splenomegaly. At this time no exact measurement of the spleen was made, but it was noted to be grossly enlarged. The liver was moderately enlarged. The haemoglobin was $7 \mathrm{~g} . / 100$ ml., and the W.B.C. 5,200/cu. mm. (71\% lymphocytes). Platelets were plentiful. A liver biopsy showed infiltration of sinusoids and periportal connective tissue by lymphocytes. No treatment was given, and he failed to keep an outpatient appointment.

Twenty-six months after his first admission he was readmitted with complaints of shortness of breath, ankle-swelling, and continued abdominal enlargement. He had been unable to work, and his clinical condition was unchanged. The spleen extended to $27 \mathrm{~cm}$. and the liver to $7 \mathrm{~cm}$. below the costal margin. The haemoglobin was 7.5 g./100 ml., W.B.C. $11,200 / \mathrm{cu}$. mm. $(65 \%$ lymphocytes), weight $68 \mathrm{~kg}$. Bone marrow showed lymphocytic infiltration. Four months after starting treatment (proguanil 100 mg. daily) he was again working. By then the haemoglobin was 14.7 g. $/ 100 \mathrm{ml}$., W.B.C. 5,500/cu. mm. (14\% lymphocytes), the spleen $5 \mathrm{~cm}$., and the liver not enlarged. Shortly after this he failed to attend for follow-up, and did not receive proguanil for two months. The spleen increased to $13 \mathrm{~cm}$. and the liver to $6 \mathrm{~cm}$. below the costal margin. The haematological findings, however, remained unchanged. Within three months of starting treatment with proguanil the spleen had reduced to $3 \mathrm{~cm}$. and the liver was not enlarged. After nine months neither the spleen nor the liver was enlarged, his haemoglobin was $15.1 \mathrm{~g} . / 100 \mathrm{ml}$., and his weight $79 \mathrm{~kg}$.

\section{Discussion}

Apart from splenomegaly the only characteristic finding in these patients was a lymphocytic increase in the blood, the bone marrow, or the liver. Periportal lymphocytic infiltration seemed to be a diagnostic feature in similar patients in East Africa (Gebbie et al., 1964) and in New Guinea (Pryor, 1967a), but the abnormality in blood and bone marrow has not been noted outside of Nigeria. We described (Allan and Watson-Williams, 1964) some curious features of chronic lymphatic leukaemia in Nigeria ; there is a preponderance of females, lymph node enlargement occurs in less than half the patients and is minimal in degree, whereas the spleen is palpable in over $80 \%$ and extends to more than $20 \mathrm{~cm}$. from the costal margin in $40 \%$, and the liver is enlarged in over $70 \%$. Thus many cases of chronic lymphatic leukaemia are distinguished from idiopathic splenomegaly only by the total white cell count. In fact, it was the surprising improvement in the anaemia and splenomegaly 
of patients with chronic lymphatic leukaemia who were treated with proguanil that led us to use it in cases of idiopathic splenomegaly. It is possible that the two conditions are closely interrelated, and typical cases represent two ends of a spectrum with many indeterminate cases between. Certainly lymphocytosis of up to $20,000 / \mathrm{cu}$. mm. may regress completely to normal on prolonged treatment with proguanil alone, but we have not succeeded in controlling lymphocytosis of over 50,000/ cu. mm. without using chlorambucil as well. Similarly, though the white cell count may be reduced to normal levels with chlorambucil, the splenomegaly and anaemia remain unchanged and respond only when proguanil is added.

Both idiopathic splenomegaly and chronic lymphatic leukaemia in Nigeria are relatively benign conditions. We do not know accurately the natural history of these diseases, but we have observed many instances of two or more years without treatment, during which time there has been either a gradual increase in anaemia and splenomegaly or no change. We have observed one patient, however, who died from reticulum-cell sarcoma 17 months after starting proguanil. Though it may eventually be demonstrated that idiopathic tropical splenomegaly is a premalignant condition, on present evidence it seems wiser to regard the lymphocytosis as a leukaemoid reaction.

The aetiology is equally obscure. Work reported from East Africa over the past three years implicated malaria, the most direct evidence being the finding of high fluorescent antibody titres for malaria (Gebbie et al., 1964). There is, however, no clinical or laboratory evidence of active malaria infection. There is no fever or rigor, and parasitaemia is if anything less intense than in the rest of the local population. Liver biopsy shows no malaria pigment. We suggest that the mechanism is that of an abnormal and possibly hyperimmune response occurring for some obscure reason in a small proportion of the population. This is associated with lymphocytic hyperplasia and splenomegaly. Possibly this cellular hyperplasia reflects a state of immune imbalance in which the cellular immune mechanism overcompensates for a defect in humoral immunity. While it has been shown that there are very high levels of fluorescent antibody in these patients there is no evidence that this is necessarily effective in malarial immunity. The splenomegaly is associated with hypervolaemia and reduced red cell life-span and thus results in anaemia (Richmond et al., 1967 ; Pryor, 1967b). Malaria prophylaxis with proguanil is probably successful in preventing the repeated augmentation of the immune mechanism, because it destroys schizonts and trophozoites and the malaria antigen is thus no longer produced. This would suppose that the hyperimmune response is dose-dependent, or occurs only as a result of an antigen present in trophozoites either within or without the red cell.
Splenectomy has been the preferred treatment elsewhere (Hamilton et al., 1967; Pryor, 1967c), but we have been reluctant to recommend this. There is a definite mortality directly related to the operation, and a potential risk to the patient of being without an organ of the immune mechanism in a tropical country. Indeed the mortality in Pryor's series was $20 \%$, two patients dying "of acute illness in the village five and three months after operation." We have observed only one death from cerebral malaria in an indigent African. $\mathrm{He}$ was 45 years old, and had had splenectomy for "lymphosarcoma of the spleen"; nine months later he was admitted with typical cerebral malaria, and blood film examination showed a parasitaemia (Plasmodium falciparum) of over $10^{i} / \mathrm{cu} . \mathrm{mm}$. He died within three hours of admission to hospital.

Our results with proguanil are at least as good as those of the five cases followed up by Hamilton et al. (1967) after splenectomy. In two respects they are better; the average weight gain was $5 \mathrm{~kg}$. compared with $4.5 \mathrm{~kg}$., and the liver was significantly reduced in size in 21 out of 22 patients with initial hepatomegaly, whereas it was unchanged after splenectomy. It may be that the liver will eventually take over the role of the spleen and become even larger in the splenectomized patient. There is a theoretical risk of patients omitting malaria prophylaxis after reduction of their immunity following prolonged usage. We think this risk is small, and we found no evidence of malaria in patients who stopped proguanil after continuous treatment for as long as three years.

It has been suggested (Hamilton et al., 1966) that tropical idiopathic splenomegaly occurs only in the malnourished. We think it is more likely that malnourishment and loss of weight are the result of the disease and in no way causal.

\section{REFERENCES}

Allan, N. C., and Watson-Williams, E. J. (1964). In Proceedings of 9th Congress of European Society of Haematology, p. 906.

Brit. med. f., 1967, 4, 614.

Dacie, J. V., and Lewis, S. M. (1963). Practical Haematology, 3rd ed. London.

Gebbie, D. A. M., Hamilton, P. J. S., Hutt, M. S. R., Marsden, P. D., Voller, A., and Wilks, N. E. (1964). Lancet, 2, 392.

Hamilton, P. J. S., Gebbie, D. A. M., Hutt, M. S. R., Lothe, F., and Wilks, N. E. (1966). Brit. med. f., 2, 548.

Hamilton, P. J. S., Richmond, J., Donaldson, G. W. K., Williams, R., Hutt, M. S. R., and Lugumba, V. (1967). Brit. med. f., 3, 823.

Pryor, D. S. (1967a). Quart. 7. Med., 36, 321.

Pryor, D. S. (1967b). Quart. F. Med., 36, 337.

Pryor, D. S. (1967c). Brit. med. F., 3, 825.

Richmond, J., Donaldson, G. W. K., Williams, R., Hamilton, P. J. S., and Hutt, M. S. R. (1967). Brit. F. Haemat., 13, 348. 